\title{
Identification of Serine-875 as an Inhibitory Phosphorylation Site in the Calcium-Sensing Receptor ${ }^{\mathbf{S}}$
}

\author{
Lenah S. Binmahfouz, (D) Patricia P. Centeno, Arthur D. Conigrave, and Donald T. Ward \\ Faculty of Biology, Medicine and Health, The University of Manchester, Manchester, United Kingdom (L.S.B., P.P.C., D.T.W.); \\ King Abdulaziz University, Jeddah, Saudi Arabia (L.S.B.); and Charles Perkins Center, School of Life and Environmental \\ Sciences, University of Sydney, Camperdown, New South Wales, Australia (A.D.C.)
}

Received February 8, 2019; accepted May 20, 2019

\section{ABSTRACT}

The calcium-sensing receptor $(\mathrm{CaS})$ is the principal controller of extracellular calcium $\left(\mathrm{Ca}_{\circ}^{2+}\right)$ homeostasis and is inhibited in vitro and in vivo by protein kinase $\mathrm{C}$ (PKC)-mediated phosphorylation at $\mathrm{CaS}^{\mathrm{T} 888}$. However, $\mathrm{PKC}$ inhibition enhances signaling even in CaSs lacking Thr-888, suggesting that an additional inhibitory site exists. An apparently equivalent PKC regulatory site in metabotropic glutamate receptor 5 (Ser-839) aligns not with $\mathrm{CaS}^{\mathrm{T} 888}$ but instead with $\mathrm{CaS}^{\mathrm{S} 875}$, which was not previously considered to be a PKC site. CaS ${ }^{\text {S875A }}$ (nonphosphorylatable) exhibited significantly enhanced $\mathrm{Ca}_{\mathrm{o}}^{2+}$ sensitivity of both intracellular $\mathrm{Ca}^{2+}$ mobilization and extracellular signal-regulated kinase $1 / 2$ activation, whereas the phosphomimetic $\mathrm{CaS}^{\mathrm{S} 875 \mathrm{D}}$ mutant exhibited a loss of function. The CaS ${ }^{S 875 A / T 888 A}$ double mutant exhibited even greater $\mathrm{Ca}_{\mathrm{o}}^{2+}$ sensitivity than $\mathrm{CaS}^{\mathrm{T} 888 \mathrm{~A}}$ alone, a response no longer enhanced by PKC inhibition. Finally, when expressed in CaS lacking its extracellular domain, the $\mathrm{CaS}^{\mathrm{S} 875 \mathrm{~A} / \mathrm{T} 888 \mathrm{~A}}$ double mutation elicited maximal activation even under control conditions, but remained sensitive to negative allosteric modulation $[N$ (2-hydroxy-3-(2-cyano-3-chlorophenoxy)propyl)-1,1-dimethyl2-(2-nephthyl)ethylamine] or $\mathrm{Ca}_{\circ}^{2+}$ removal. Therefore, we have now identified $\mathrm{CaS}^{\mathrm{S875}}$ as the missing PKC phosphorylation site that, together with $\mathrm{CaS}^{\mathrm{T} 888}$, shapes the $\mathrm{CaS}$ signaling that underpins $\mathrm{Ca}_{\circ}^{2+}$ homeostasis. Together with the inactive form of the CaS extracellular domain, these sites attenuate $\mathrm{Ca}_{\circ}^{2+}$ sensitivity to attain appropriate physiologic $\mathrm{Ca}_{\circ}^{2+}$ sensing.

\section{SIGNIFICANCE STATEMENT}

Serine-875 represents the missing inhibitory PKC phosphorlyation site in CaS that in tandem with Thr-888 controls receptor activity.

\section{Introduction}

The calcium-sensing receptor $(\mathrm{CaS})$ is the principal controller of extracellular calcium $\left(\mathrm{Ca}^{2+}\right)$ homeostasis, suppressing both parathyroid hormone secretion and renal calcium reabsorption in response to high $\mathrm{Ca}_{\mathrm{o}}^{2+}$ concentration. When first cloned, CaS was predicted to contain five protein kinase $\mathrm{C}$ (PKC) consensus sequences: two in the first and third intracellular loops, Thr-646 and Ser-794; and three in the CaS intracellular tail, Thr-888, Ser-895, and Ser-915 (Garrett et al., 1995; Bai et al., 1998). Previous results from this laboratory and others (Bai et al., 1998; Davies et al., 2007; Young et al., 2014) have shown that one of these residues, $\mathrm{CaS}^{\mathrm{T} 888}$, represents the key phosphorylation site responsible for PKC-mediated inhibition of CaS-mediated intracellular $\mathrm{Ca}^{2+}\left(\mathrm{Ca}_{\mathrm{i}}^{2+}\right)$ mobilization in vitro. In humans, mutation of $\mathrm{CaS}^{\mathrm{T} 888}$ to a nonphosphorylatable methionine produces a

This work was funded by a studentship from King Abdulaziz University, Jeddah, Saudi Arabia (to L.S.B.) and the Marie Sklodowska-Curie Action of the European Union's Horizon 2020 program [Grant 675228] as part of the CaSR Biomedicine Network (to P.P.C.)

The authors declare no conflict of interest.

https://doi.org/10.1124/mol.119.116178.

S This article has supplemental material available at molpharm.aspetjournals.org. gain-of-function CaS, resulting in autosomal dominant hypocalcaemia (Lazarus et al., 2011). Bai et al. (1998) reported that while the other four known PKC sites play little or no role in mediating PKC's functional effect, $\mathrm{CaS}^{\mathrm{T} 888}$ cannot be the sole determinant of the PKC effect. Furthermore, in the current laboratory, it was shown that $\mathrm{CaS}^{\mathrm{T} 888 \mathrm{~A}}$ still causes $\mathrm{Ca}_{\mathrm{i}}^{2+}$ oscillations in some cells (at least in the presence of $2 \mathrm{mM}$ $\mathrm{Ca}_{\mathrm{o}}^{2+}$ ), and PKC activation with the phorbol ester phorbol 12myristate 13-acetate (PMA) elicits a partial inhibitory effect in $\mathrm{CaS}^{\mathrm{T} 888 \mathrm{~A}}$ (Davies et al., 2007) and $\mathrm{CaS}^{\mathrm{T} 888 \mathrm{M}}$ (Lazarus et al., 2011) expressing cells. Together, these findings have suggested the existence of an additional PKC site in CaS.

The idea of PKC-mediated inhibition of class C G proteincoupled receptors (GPCRs) came initially not from CaS but from the structurally homologous metabotropic glutamate receptor 5 (mGluR5) (Dale et al., 2001; Hermans and Challiss, 2001), with Ser-839 being shown to be the most likely mediator of the PKC response (Kim et al., 2005). Indeed, mutation of Ser-839 in mGluR5 to alanine (mGluR5 ${ }^{\text {S839A }}$ ) was shown to prevent $\mathrm{Ca}_{\mathrm{i}}^{2+}$ oscillations in HeLa cells (Kim et al., 2005). Interestingly, mGluR5 ${ }^{\mathrm{S} 839}$ does not align with $\mathrm{CaS}^{\mathrm{T} 888}$ or indeed with any of the known PKC consensus sequences in the $\mathrm{CaS}$. Instead, it aligns with $\mathrm{CaS}^{\mathrm{S} 875}$, a residue not

ABBREVIATIONS: $\mathrm{Ca}_{i}^{2+}$, intracellular $\mathrm{Ca}^{2+} ; \mathrm{Ca}_{\circ}^{2+}$, extracellular $\mathrm{Ca}^{2+} ; \mathrm{CaS}$, calcium-sensing receptor; CaS ${ }^{\mathrm{WT}}$, wild-type calcium-sensing receptor; ECD, extracellular domain; ERK1/2, extracellular signal-regulated kinase 1/2; GFX, GF109203X (bisindolylmaleimide I); GPCR, G protein-coupled receptor; HEK-293, human embryonic kidney 293; ICD, intracellular domain, mGluR5, metabotropic glutamate receptor 5; PKC, protein kinase C; PMA, phorbol 12- myristate 13-acetate; TMD, transmembrane domain. 
previously considered likely to be a PKC site. In support of this idea, Huttlin et al. (2010) reported murine phospho-proteomic data that included evidence of phosphorylation at $\mathrm{CaS}^{\mathrm{S} 875}$. Furthermore, while only five CaS residues were originally proposed to be PKC consensus sequences (Garrett et al., 1995), the NetPhos database (NetPhos 3.1 Server; http:// www.cbs.dtu.dk/services/NetPhos-3.1/) predicts $\mathrm{CaS}$ as having as many as 15 potential PKC sites, including both $\mathrm{CaS}^{\mathrm{S} 875}$ and $\mathrm{CaS}^{\mathrm{T} 888}$.

Therefore, the aim of this study was to evaluate the effect of mutating Ser-875 on CaS-mediated signaling to assess whether it likely represents the missing PKC site (Bai et al., 1998) in the intracellular domain (ICD). This was investigated both in wild-type $\mathrm{CaS}\left(\mathrm{CaS}^{\mathrm{WT}}\right)$ and also in a $\mathrm{CaS}$ construct (Rho-C-hCaS) lacking most of the extracellular domain [(ECD), residues 1-599], thus leaving just the seventransmembrane domain (TMD) and N-terminal ICD as described previously (Zhao et al., 1999).

\section{Materials and Methods}

Cell Culture. Human embryonic kidney 293 (HEK-293) cells transfected with $\mathrm{CaS}^{\mathrm{WT}}$ were grown in Dulbecco's modified Eagle's medium supplemented with 10\% heat-inactivated FBS (SigmaAldrich, Gillingham, UK). To avoid cell death, gain-of-function mutant cell lines were routinely cultured in low $\mathrm{Ca}^{2+}$ RPMI (containing $0.42 \mathrm{mM} \mathrm{CaCl}_{2}$ ) instead of Dulbecco's modified Eagle's medium (containing $1.8 \mathrm{mM} \mathrm{CaCl}_{2}$ ).

Mutagenesis. Mutations were introduced into the wild-type human parathyroid CaS by site-directed mutagenesis using the QuikChange lightning site-directed mutagenesis kit in accordance with the manufacturer's instructions (Agilent Technologies Ltd., Cheadle, UK). HEK-293 cells were then transiently transfected with wild-type or mutant receptors using FuGENE6 (Promega, Southampton, UK). For stable expression, vectors were linearized prior to transfection and the resulting CaS-expressing cells were selected using Hygromycin (Duchefa Biochemie). Clonal cell lines were then established. The RhoC-hCaS mutant was obtained from R. Mun (The Charles Perkins Centre, The University of Sydney, Camperdown, Australia) having been initially generated by Zhao et al. (1999). All mutations were subsequently verified by the DNA sequencing facility at The University of Manchester.

Immunoblotting. CaS expression was demonstrated by immunoblotting as described previously (Ward et al., 1998) using an anti-CaS mouse monoclonal antibody (ADD; amino acids 214-235 of human CaS; Fisher Scientific, Loughborough, UK). In brief, cells were lysed on ice in a detergent-containing HEPES buffer supplemented with protease inhibitors and $1 \mathrm{mM} N$-ethylmaleimide. The lysate was centrifuged at $12,000 \mathrm{~g}$ (for 10 minutes at $4^{\circ} \mathrm{C}$ ) and the supernatant was solubilized in Laemmli buffer at $65^{\circ} \mathrm{C}$.

Intracellular Calcium Imaging. CaS-induced $\mathrm{Ca}_{i}^{2+}$ mobilization was assayed by epifluorescence microscopy as described previously (Davies et al., 2007) after loading cells with Fura-2 AM (Life Technologies Ltd., Paisley, UK). CaS-transfected cells were exposed to increasing concentrations of $\mathrm{Ca}_{0}^{2+}$ in experimental buffer $[20 \mathrm{mM}$ HEPES (pH 7.4), $125 \mathrm{mM} \mathrm{NaCl}, 4 \mathrm{mM} \mathrm{KCl}, 0.5 \mathrm{mM} \mathrm{CaCl}_{2}, 0.5 \mathrm{mM}$ $\mathrm{MgCl}_{2}$, and $5.5 \mathrm{mM}$ glucose] at room temperature to compare relative $\mathrm{Ca}_{\mathrm{o}}^{2+}$ sensitivities between the receptors. The coverslips were mounted in a perfusion chamber (Warner Instruments, Hamden, CT) and fluorescence visualized using a Nikon Diaphot inverted microscope equipped with a digital camera charge-coupled device.

Extracellular Signal-Regulated Kinase 1/2 Phosphorylation. Extracellular signal-regulated kinase 1/2 (ERK1/2) phosphorylation in CaS-transfected cells was assayed as described previously (Ward et al., 2002). In brief, cells were exposed to various concentrations of $\mathrm{Ca}_{\mathrm{o}}^{2+}$ in experimental buffer at $37^{\circ} \mathrm{C}$ for 10 minutes prior to lysis on ice in detergent-containing buffer supplemented with protease and phosphatase inhibitors. ERK1/2 phosphorylation was then determined by semiquantitative immunoblotting using a phosphospecific antibody (Cell Signaling Technology).

Data and Statistical Analysis. The data are presented as mean \pm S.D. (for $\mathrm{pEC}_{50}$ variance; shown as insets in the graphs) or mean \pm S.E.M. (for precision of the individual responses, shown graphically). Statistical significance between $\mathrm{pEC}_{50}$ values $(P$ values $<0.05)$ was determined by Student's unpaired/paired $t$ test or one-way ANOVA followed by Dunnett's or Tukey's multiple comparisons test as appropriate (GraphPad Prism version 7). For the $\mathrm{Ca}_{\mathrm{i}}^{2+}$ assay, the area under the curve of the Fura-2 ratios (MetaFluor) for all cells in a field of view over a given time range was calculated using GraphPad Prism (version 7) with resulting curves produced using a sigmoidal dose-response (variable slope) equation.

\section{Results}

Effect of $\mathrm{CaS}^{\mathrm{S} 875 \mathrm{~A}}$ and $\mathrm{CaS}^{\mathrm{S} 875 \mathrm{D}}$ Phospho-Mutations on $\mathrm{Ca}_{\mathrm{o}}^{2+}$-Induced $\mathrm{Ca}_{\mathbf{i}}^{2+}$ Mobilization. The key inhibitory PKC site in mGluR5 (mGluR5 ${ }^{\mathrm{S} 839}$ ) aligns in the CaS not with the recognized inhibitory PKC site $\mathrm{CaS}^{\mathrm{T} 888}$ (Bai et al., 1996; Davies et al., 2007) but instead with $\mathrm{CaS}^{\mathrm{S} 875}$ (Supplemental Fig. 1), which has not been previously considered to be a PKC site (Garrett et al., 1995; Bai et al., 1996). Thus, to examine the potential role of $\mathrm{CaS}^{\mathrm{S} 875}$ phosphorylation on receptor signaling, this residue was mutated either to a nonphosphorylatable alanine residue $\left(\mathrm{CaS}^{\mathrm{S} 875 \mathrm{~A}}\right)$ or to a phosphomimetic aspartic acid residue $\left(\mathrm{CaS}^{\mathrm{S} 875 \mathrm{D}}\right)$ in $\mathrm{CaS}^{\mathrm{WT}}$. Subsequently, both mutated receptors were transiently transfected into HEK-293 cells, and CaS-induced $\mathrm{Ca}_{\mathrm{i}}^{2+}$ mobilization was measured in response to increasing concentrations of $\mathrm{Ca}_{0}^{2+}(0.5-10 \mathrm{mM})$. As shown in Fig. 1, CaS ${ }^{\mathrm{S} 875 \mathrm{~A}}$ was a gain-of-function mutation showing enhanced receptor sensitivity to $\mathrm{Ca}_{0}^{2+}$ relative to $\mathrm{CaS}^{\mathrm{WT}}\left(\mathrm{EC}_{50}, 2.3 \mathrm{CaS}^{\mathrm{S} 875 \mathrm{~A}}\right.$ vs. $\left.3.5 \mathrm{mM} \mathrm{CaS}{ }^{\mathrm{WT}} ; P<0.01\right)$. A similar gain of function was seen in HEK-293 cells stably expressing the $\mathrm{CaS}^{\mathrm{S} 875 \mathrm{~A}}$ mutation (Supplemental Figs. 2 and 3). In contrast, $\mathrm{CaS}^{\mathrm{S} 875 \mathrm{D}}$ exhibited decreased $\mathrm{Ca}_{0}^{2+}$ sensitivity relative to $\mathrm{CaS}^{\mathrm{WT}}$, indicating that it is a loss-of-function mutation $\left(\mathrm{EC}_{50}, 4.7 \mathrm{CaS}^{\mathrm{S} 875 \mathrm{D}}\right.$ vs. $\left.3.5 \mathrm{mM} \mathrm{CaS}^{\mathrm{WT}} ; P<0.01\right)$ (Fig. 1).

$\mathrm{CaS}^{\mathrm{T} 888 \mathrm{~A}}$ and $\mathrm{CaS}^{\mathrm{S} 875 \mathrm{~A}}$ Mutations Enhance $\mathrm{Ca}_{\mathrm{o}}^{2+}$ Induced ERK1/2 Phosphorylation. The relative responses of $\mathrm{CaS}^{\mathrm{T} 888 \mathrm{~A}}$ and $\mathrm{CaS}^{\mathrm{S} 875 \mathrm{~A}}$ on $\mathrm{Ca}_{\mathrm{o}}^{2+}$-stimulated ERK1/2 phosphorylation were next compared with $\mathrm{CaS}^{\mathrm{WT}}$ control responses using HEK-293 cells expressing each receptor stably. In agreement with the $\mathrm{Ca}_{\mathrm{i}}^{2+}$ mobilization data, $\mathrm{CaS}^{\mathrm{S} 875 \mathrm{~A}}$ enhanced $\mathrm{Ca}_{\mathrm{o}}^{2+}$-induced phosphorylated ERK1/2 activation relative to $\mathrm{CaS}^{\mathrm{WT}}$ control $\left(\mathrm{EC}_{50}, 1.9 \mathrm{CaS}^{\mathrm{S} 875 \mathrm{~A}}\right.$ vs. $3.8 \mathrm{mM} \mathrm{CaS}^{\mathrm{WT}} ; P<0.01$ ) (Fig. 2). A similar gain of function was seen, as expected, in $\mathrm{CaS}^{\mathrm{T} 888 \mathrm{~A}}$-expressing cells $\left(\mathrm{EC}_{50}, 2.2\right.$ $\mathrm{CaS}^{\mathrm{T} 888 \mathrm{~A}}$ vs. $4.4 \mathrm{mM} \mathrm{CaS}^{\mathrm{WT}} ; P<0.01$ ). Equal protein loading on the blots was confirmed by uniform $\beta$-actin expression. An equivalent gain of function for $\mathrm{Ca}_{i}^{2+}$ mobilization by the $\mathrm{CaS}^{\mathrm{T} 888 \mathrm{~A}}$ stably expressing cells is shown in Supplemental Fig. 4. There is evidence that forward trafficking of the CaS can be modulated by its association with 14-3-3 protein under the control of $\mathrm{CaS}^{\mathrm{S} 899}$ phosphorylation (Grant et al., 2011, 2015). As such, it is important to consider whether $\mathrm{CaS}^{\mathrm{S} 875}$ phosphorylation affects functional signaling directly or merely as a determinant of cell surface localization. To examine this, HEK-293 cells were transiently transfected with $\mathrm{CaS}^{\mathrm{WT}}$, $\mathrm{CaS}^{\mathrm{S} 875 \mathrm{~A}}$, and $\mathrm{CaS}^{\mathrm{T} 888 \mathrm{~A}}$, and the membrane localization of 


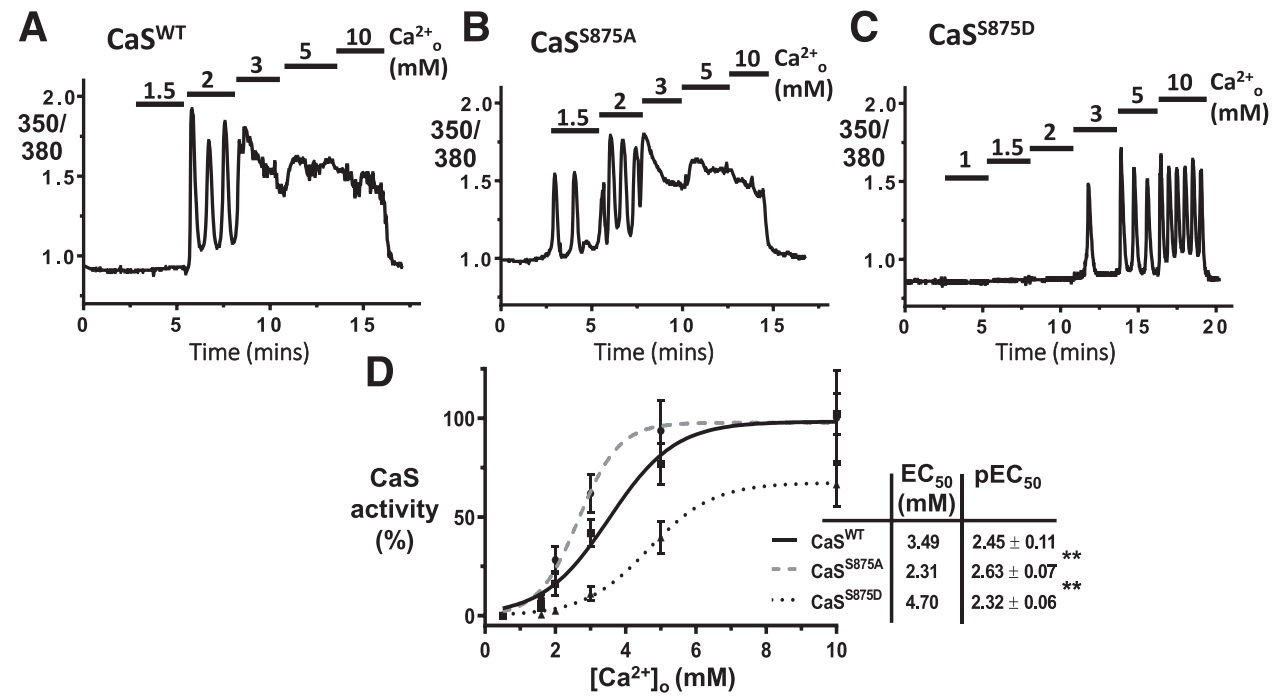

Fig. 1. $\mathrm{CaS}^{\mathrm{S} 875}$ acts as an inhibitory phosphorylation site. Fura-2-loaded HEK293 cells were transiently transfected with either (A) $\mathrm{CaS}^{\mathrm{WT}}(\mathrm{B}) \mathrm{CaS}^{\mathrm{S} 875 \mathrm{~A}}$ or $(\mathrm{C}) \mathrm{CaS}^{\mathrm{S} 875 \mathrm{D}}$, and then exposed to increasing $\mathrm{Ca}_{0}^{2+}$ concentrations $(0.5-10 \mathrm{mM})$ to determine the effect of the putative phosphorylation site $\mathrm{CaS}^{\mathrm{S} 875}$ on $\mathrm{Ca}_{\mathrm{i}}^{2+}$ mobilization. The representative traces show the $\mathrm{Ca}_{\mathrm{i}}^{2+}$ changes (Fura-2 ratio) in single cells from the field of view. The whole field-of-view changes in $\mathrm{Ca}_{i}^{2+}$ concentration are shown as concentration-effect curves in (D). ${ }^{* * P}<0.01$ vs. $\mathrm{CaS}^{\mathrm{WT}}$ by one-way ANOVA with Dunnett's post hoc test. Data are representative of three independent experiments $(n \geq 6$ coverslips).

these receptors was then analyzed using a surface biotinylation assay. As shown in Supplemental Fig. 5 we saw no evidence of substantive changes in cell surface localization in receptors lacking Ser-875 or Thr-888. However, taken together these observations confirm that $\mathrm{CaS}^{\mathrm{S} 875 \mathrm{~A}}$ is a gain-offunction mutation, with a similar impact on $\mathrm{Ca}_{\mathrm{o}}^{2+}$-stimulated signaling responses to $\mathrm{CaS}^{\mathrm{T} 888 \mathrm{~A}}$.

Effect of $\mathrm{CaS}^{\text {S875A/T888A }}$ Double Mutation on CaS Signaling. Since both $\mathrm{CaS}^{\mathrm{S} 875 \mathrm{~A}}$ and $\mathrm{CaS}^{\mathrm{T} 888 \mathrm{~A}}$ exhibited gain of function by two different experimental readouts, it was next decided to introduce both mutations in the same receptor to test whether their effects are additive. This question was asked since Bai et al. (1996) found that PKC inhibition could further enhance $\mathrm{CaS}^{\mathrm{T} 888 \mathrm{~A}}$ signaling, suggesting that another
PKC site may contribute additional receptor modulation. The resulting $\mathrm{CaS}^{\mathrm{S} 875 \mathrm{~A} / \mathrm{T} 888 \mathrm{~A}}$ double mutant was tested for its effect on $\mathrm{Ca}_{\mathrm{i}}^{2+}$ mobilization as previously detailed in both transiently (Supplemental Fig. 6) and stably transfected (Fig. 3) HEK-293 cells. In both cases, the doubly mutated $\mathrm{CaS}^{\mathrm{S} 875 \mathrm{~A} / \mathrm{T} 888 \mathrm{~A}}$ exhibited significantly lower $\mathrm{EC}_{50}$ values and increased sensitivity for $\mathrm{Ca}_{\mathrm{o}}^{2+}$ than for the $\mathrm{CaS}^{\mathrm{T} 888 \mathrm{~A}}$ mutant (stable, 1.8 $\mathrm{CaS}^{\mathrm{S} 875 \mathrm{~A} / \mathrm{T} 888 \mathrm{~A}}$ vs. $2.4 \mathrm{mM} \mathrm{CaS}^{\mathrm{T} 888 \mathrm{~A}} ; P<0.01$ ) (Fig. 3). It was further noted that the $\mathrm{CaS}^{\mathrm{S} 875 \mathrm{~A} / \mathrm{T} 888 \mathrm{~A}}$ double mutant completely abolished $\mathrm{Ca}_{\mathrm{i}}^{2+}$ oscillations, which $\mathrm{CaS}^{\mathrm{T} 888 \mathrm{~A}}$ failed to do at lower $\mathrm{Ca}_{o}^{2+}$ concentrations.

Similar to its effect on $\mathrm{Ca}_{\mathrm{i}}^{2+}$ mobilization, the $\mathrm{CaS}^{\mathrm{S} 875 \mathrm{~A} / \mathrm{T} 888 \mathrm{~A}}$ double mutant also increased $\mathrm{Ca}_{\mathrm{o}}^{2+}$ sensitivity of ERK1/2 phosphorylation compared with $\mathrm{CaS}^{\mathrm{T} 888 \mathrm{~A}}$ alone $\left(\mathrm{EC}_{50}, 2.5\right.$ vs.

A i

CaSwT

$\mathrm{CaS}^{\mathrm{T} 888 \mathrm{~A}}$

ii CaSwT

CaS $875 \mathrm{~A}$

$\begin{array}{llllll}0.51 .52 .53 .5 & 5 & .51 .52 .53 .5 & 0.51 .52 .53 .55 & \overline{51.52 .53 .55}\end{array}$

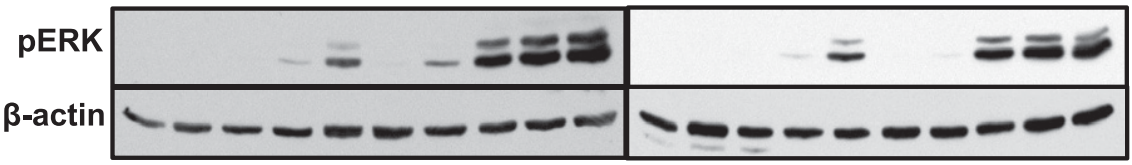

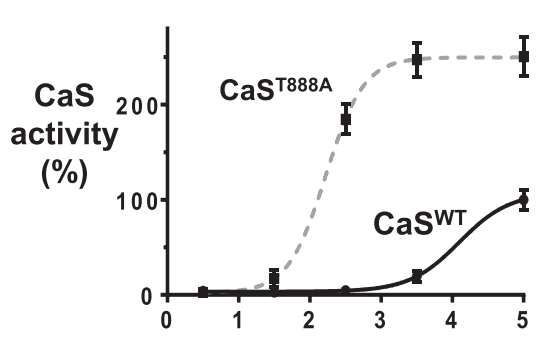

B i $\left[\mathrm{Ca}^{2+}\right]_{0}(\mathrm{mM})$

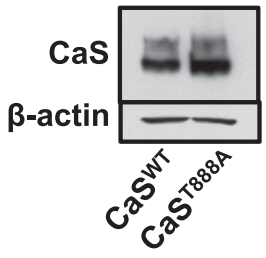

Fig. 2. $\mathrm{CaS}^{\mathrm{T} 888 \mathrm{~A}}$ and $\mathrm{CaS}^{\mathrm{S} 875 \mathrm{~A}}$ mutations increase CaS-induced ERK1/2 phosphorylation. (A) HEK-293 cells were stably transfected with either $\mathrm{CaS}^{\mathrm{WT}}$, $\mathrm{CaS}^{\mathrm{T} 888 \mathrm{~A}}$ (i) or $\mathrm{CaS}^{\mathrm{S} 875 \mathrm{~A}}$ (ii), and then stimulated with various $\mathrm{Ca}_{0}^{2+}$ concentrations $(0.5-5 \mathrm{mM})$ for 10 minutes to determine the effect of mutating the two phosphorylation sites on extracellular signalregulated kinase (pERK) activation. Representative western blots indicating ERK1/2 phosphorylation, together with $\beta$-actin loading control, are shown above the resulting concentration-effect curves in each graph. ERK1/2 responses are expressed as a percentage of $\mathrm{CaS}^{\mathrm{WT}}$ maximal response in each experiment. $* * P<0.01 \mathrm{CaS}^{\mathrm{T} 888 \mathrm{~A}}$ vs. $\mathrm{CaS}^{\mathrm{WT}}(n=6$ from three independent experiments) and $\mathrm{CaS}^{\mathrm{S} 875 \mathrm{~A}}$ vs. $\mathrm{CaS}^{\mathrm{WT}}$ ( $n=7$ from three independent experiments) $\mathrm{pEC}_{50}$ values by unpaired $t$ test, $n \geq 8$ from three independent experiments. (B) CaS immunoblots showing similar receptor abundance between cell lines, with their protein loading equivalence confirmed by $\beta$-actin expression. 


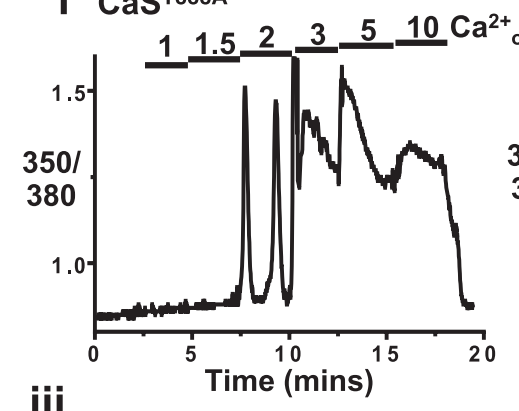

ii CaS $5875 A / 7888 A$
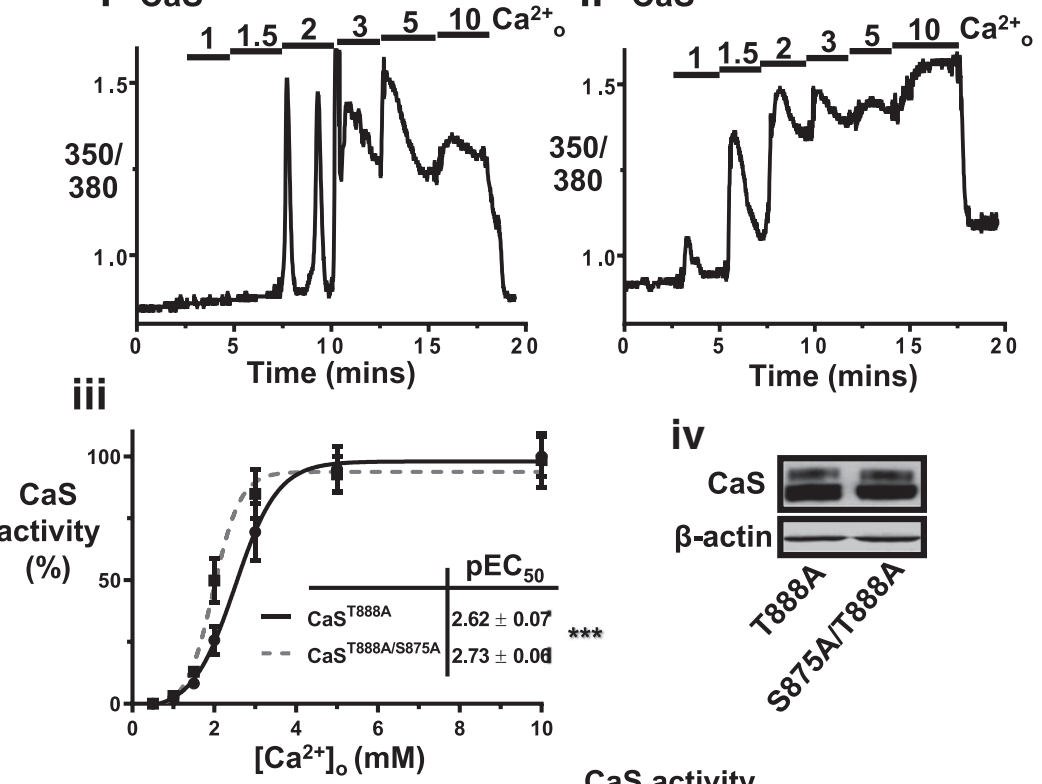

B

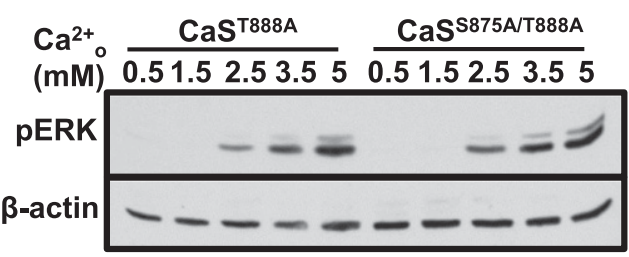

iv

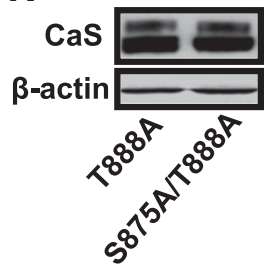

CaS activity

(\%)

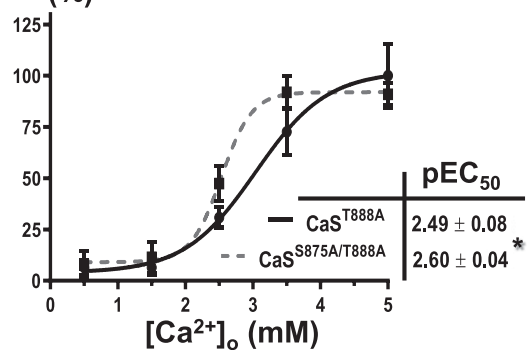

Fig. 3. $\mathrm{CaS}^{\mathrm{S} 875 \mathrm{~A} / \mathrm{T} 888 \mathrm{~A}}$ double mutant is more sensitive to $\mathrm{Ca}_{\mathrm{o}}^{2+}$ than $\mathrm{CaS}^{\mathrm{T} 888 \mathrm{~A}}$ alone. (A) Fura2-loaded HEK-293 cells stably transfected with either $\mathrm{CaS}^{\mathrm{T} 888 \mathrm{~A}}$ (i) or $\mathrm{CaS}^{\mathrm{S} 875 \mathrm{~A} / \mathrm{T} 888 \mathrm{~A}}$ (ii) were stimulated with increasing $\mathrm{Ca}_{\mathrm{o}}^{2+}$ concentrations (0.5-10 mM). The two panels show $\mathrm{Ca}_{\mathrm{i}}^{2+}$ traces from representative single cells. The resulting concentration-effect curves are shown in (iii). $* * P<0.01$ for $\mathrm{CaS}^{\mathrm{T} 888 \mathrm{~A}}$ vs. $\mathrm{CaS} \mathrm{S}^{\mathrm{S} 875 \mathrm{~A} / \mathrm{T} 888 \mathrm{~A}}$ by unpaired $t$ test; $n \geq 9$ coverslips from three independent experiments. Equivalence of $\mathrm{CaS}$ abundance between cell lines is shown in (iv), with $\beta$-actin loading control. (B) Representative western blots showing ERK1/2 phosphorylation and $\beta$-actin immunoreactivity in the same cell lines as before, stimulated with various $\mathrm{Ca}_{\mathrm{o}}^{2+}$ concentrations $(0.5-5 \mathrm{mM})$ for 10 minutes. The resulting concentration-effect relationship is shown on the right. ERK1/2 responses are expressed as a percentage of $\mathrm{CaS}^{\mathrm{T} 888 \mathrm{~A}}$ maximal response in each experiment. $* P<0.05$ $\mathrm{EC}_{50}$ values for $\mathrm{CaS}^{\mathrm{T} 888 \mathrm{~A}}$ vs. $\mathrm{CaS}^{\mathrm{S} 875 \mathrm{~A} / \mathrm{T} 888 \mathrm{~A}}$ by unpaired $t$ test; $n \geq 6$ from three independent experiments.
3.2 respectively; $P<0.05$ ) (Fig. 3B), further demonstrating the additive effect of the two mutations. Overall, these observations confirm that the double mutant receptor $\mathrm{CaS}^{\mathrm{S} 875 \mathrm{~A} / \mathrm{T} 888 \mathrm{~A}}$ was significantly more sensitive to $\mathrm{Ca}_{\mathrm{o}}^{2+}$ than $\mathrm{CaS}^{\mathrm{T} 888 \mathrm{~A}}$ alone with respect to both $\mathrm{Ca}_{\mathrm{i}}^{2+}$ mobilization and ERK1/2 activation.

To confirm that stable transfection with the double mutant receptor $\mathrm{CaS}^{\mathrm{S} 875 \mathrm{~A} / \mathrm{T} 888 \mathrm{~A}}$ had not increased $\mathrm{G} \alpha_{\mathrm{q}}$-mediated $\mathrm{Ca}_{\mathrm{i}}^{2+}$ mobilization in a nonspecific manner, the effect of carbachol on $\mathrm{Ca}_{\mathrm{i}}^{2+}$ mobilization was also tested. Carbachol also elicits oscillatory $\mathrm{Ca}_{\mathrm{i}}^{2+}$ mobilization in wild-type HEK-293 cells (Supplemental Fig. 7i), most likely via the muscarinic acetylcholine receptor (Atwood et al., 2011). However, the CaS ${ }^{\text {S875A/T888A }}$ double mutant failed to increase carbachol sensitivity for $\mathrm{Ca}_{\mathrm{i}}^{2+}$ mobilization, suggesting that $\mathrm{CaS}^{\mathrm{S} 875 \mathrm{~A} / \mathrm{T} 888 \mathrm{~A}}$ gain of function is not due to a nonspecific increase in $\mathrm{G} \alpha_{\mathrm{q}}$-mediated $\mathrm{Ca}_{\mathrm{i}}^{2+}$ mobilization or an artifact of transfection (Supplemental Fig. 7, ii-iv). Indeed, carbachol responsiveness was inhibited in cells expressing $\mathrm{CaS}^{\mathrm{S} 875 \mathrm{~A} / \mathrm{T} 888 \mathrm{~A}}\left(\mathrm{EC}_{50}, 7.5\right.$ vs. 3.2 $\left.\mu \mathrm{M} \mathrm{CaS}{ }^{\mathrm{WT}} ; P<0.01\right)$. The cause of this reduced carbachol responsiveness was not investigated further.

PKC Inhibition Fails to Further Enhance CaS ${ }^{\text {S875A/T888A }}$ Signaling. Having confirmed that the double mutant $\mathrm{CaS}^{\mathrm{S} 875 \mathrm{~A} / \mathrm{T} 888 \mathrm{~A}}$ exhibits significantly greater $\mathrm{Ca}_{\mathrm{o}}^{2+}$ responsiveness than for $\mathrm{CaS}^{\mathrm{T} 888 \mathrm{~A}}$ alone, we next tested whether PKC inhibition could elicit additional signal enhancement suggestive of yet further PKC sites. For this, CaS ${ }^{\mathrm{S} 875 \mathrm{~A} / \mathrm{T} 888 \mathrm{~A}}$ stably expressing cells were treated with or without bisindolylmaleimide
I [GF109203X (GFX), $250 \mathrm{nM}$ ], a nonspecific PKC inhibitor, for 30 minutes, and then co-stimulated with increasing concentrations of $\mathrm{Ca}_{\mathrm{o}}^{2+}(0.5-5 \mathrm{mM})$, with $\mathrm{Ca}_{\mathrm{i}}^{2+}$ mobilization assayed as previously described (Fig. 4). For comparison, $\mathrm{CaS}^{\mathrm{WT}}$ and $\mathrm{CaS}^{\mathrm{T} 888 \mathrm{~A}}$ cells were tested alongside one another in these experiments. As expected, GF109203X treatment significantly increased the sensitivity of both $\mathrm{CaS}^{\mathrm{WT}}\left(\mathrm{EC}_{50} ; 5.6\right.$ control vs. $3.3 \mathrm{mM}$ GFX; $P<0.001)$ and $\mathrm{CaS}^{\mathrm{T} 888 \mathrm{~A}}\left(\mathrm{EC}_{50} ; 2.4\right.$ control vs. $1.2 \mathrm{mM}$ GFX; $P<0.001$ ) for $\mathrm{Ca}_{\mathrm{o}}^{2+}$. However, there was no difference in CaS-induced $\mathrm{Ca}_{\mathrm{i}}^{2+}$ mobilization between $\mathrm{CaS}^{\mathrm{S} 875 \mathrm{~A} / \mathrm{T} 888 \mathrm{~A}}$ double mutants treated without or with GF109203X; that is, they both increased CaS sensitivity to a virtually identical extent $\left(\mathrm{EC}_{50}, 1.8\right.$ control vs. $1.7 \mathrm{mM}$ GFX; $P=0.86$ ). These data suggest that the positive effect of PKC inhibition can be replaced entirely by alanine mutation of both inhibitory phosphorylation sites, Ser-875 and Thr-888, thus indicating that Ser-875 is another PKC site.

Effect of $\mathrm{CaS}^{\mathrm{T888A}}$ and $\mathrm{CaS}^{\mathrm{S875A}}$ Mutations on Rho-ChCaS-Induced $\mathbf{C a}_{\mathbf{i}}^{\mathbf{2 +}}$ Mobilization. Having established the dual inhibitory effect of $\mathrm{CaS}^{\mathrm{T} 888}$ and $\mathrm{CaS}^{\mathrm{S} 875}$ on $\mathrm{CaS}$ signaling, the role of both phosphorylation sites was next tested in the context of a $\mathrm{CaS}$ construct lacking the entire ECD (Rho-C-hCaS) to assess their inhibitory effects on the TMD core of the receptor. The hypothesis was that if the ECD of the $\mathrm{CaS}$ is responsible for ligand-dependent activation (Bräuner-Osborne et al., 1999; Geng et al., 2016; Zhang et al., 2016), then relieving the PKC-mediated inhibitory constraints on the receptor might result in ligand-independent 

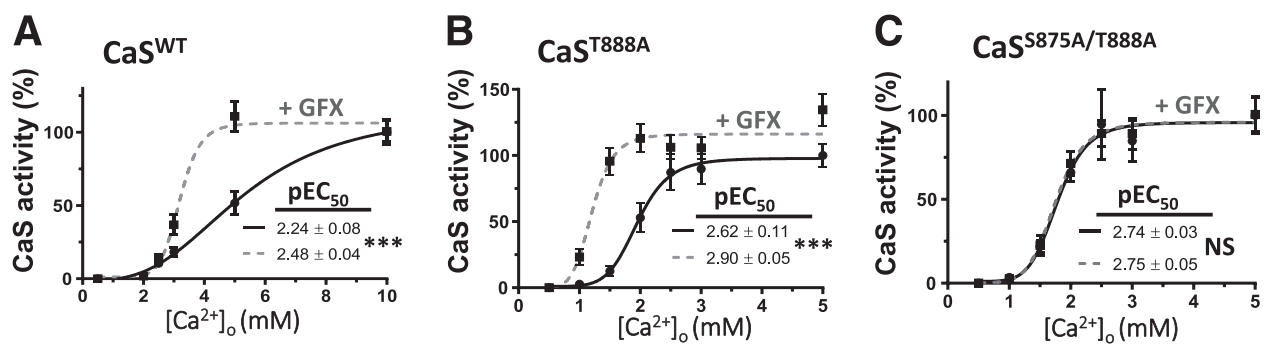

Fig. 4. PKC inhibition does not further enhance $\mathrm{CaS}^{\mathrm{S} 875 \mathrm{~A} / \mathrm{T} 888 \mathrm{~A}}$ responses. Fura-2-loaded HEK-293 cells stably transfected with either CaS ${ }^{\mathrm{WT}}$ (A), $\mathrm{CaS}^{\mathrm{T} 888 \mathrm{~A}}(\mathrm{~B})$, or $\mathrm{CaS}^{\mathrm{S} 875 \mathrm{~A} / \mathrm{T} 888 \mathrm{~A}}$ (C) were stimulated with increasing concentrations of $\mathrm{Ca}_{0}^{2+}$ in the absence or presence of the PKC inhibitor GF109203X $(\mathrm{GFX}, 250 \mathrm{nM})$. The concentration-effect curves show significantly enhanced $\mathrm{Ca}_{\mathrm{o}}^{2+}$ sensitivity following GF109203X treatment in $\mathrm{CaS}^{\mathrm{WT}}$ and $\mathrm{CaS}^{\mathrm{T} 888 \mathrm{~A}}$ cells but not in $\mathrm{CaS}^{\mathrm{S} 875 \mathrm{~A} / \mathrm{T} 888 \mathrm{~A}}$ double mutant cells. $* * * P<0.001$, NS, not significant for control vs. GF109203X by unpaired $t$ test. $n \geq 6$ coverslips from two independent experiments.

activation of the CaS. In such a case, mutation of the inhibitory phosphorylation sites might enhance responsiveness even in a headless CaS.

Rho-C-hCaS lacks most of the ECD (residues 1-599); therefore, it contains only the 7TMD and the carboxylterminal ICD with a stop codon at residue 903 as described previously (Zhao et al., 1999) (Supplemental Fig. 8A). To facilitate cell surface expression, the start of this truncated $\mathrm{CaS}$ was fused to 20 amino acid residues of the $\mathrm{N}$-terminus of bovine rhodopsin (MNGTEGPNFYVPFSNKTGVV). First, Rho-C-hCaS was transiently transfected into HEK-293 cells, and then the effect of increasing $\mathrm{Ca}_{\mathrm{o}}^{2+}$ concentrations (up to $10 \mathrm{mM}$ ) on $\mathrm{Ca}_{\mathrm{i}}^{2+}$ mobilization was assayed as previously described. In contrast to $\mathrm{CaS}^{\mathrm{WT}}$, which elicits oscillatory signaling, Rho-C-hCaS elicited only transient or sustained $\mathrm{Ca}_{\mathrm{i}}^{2+}$ mobilization (Supplemental Fig. 8B). It should be noted that no $\mathrm{Ca}_{\mathrm{i}}^{2+}$ mobilization was seen under these conditions in nontransfected HEK-293 cells (data not shown). Moreover, the effect of PKC inhibition on Rho-C-hCaS signaling was tested. For this, HEK-293 cells transiently transfected with Rho-C-hCaS were first exposed to $3 \mathrm{mM} \mathrm{Ca}_{\mathrm{o}}^{2+}$ to elicit $\mathrm{Ca}_{i}^{2+}$ mobilization and then cotreated with $250 \mathrm{nM}$ of GF102903X. Indeed, GF102903X enhanced Rho-C-hCaSinduced $\mathrm{Ca}_{\mathrm{i}}^{2+}$ mobilization in response to $3 \mathrm{mM} \mathrm{Ca}_{0}^{2+}(P<0.05)$ (Supplemental Fig. 8C).

Next, it was examined whether mutating Thr-888 and/or Ser-875 to alanine can also increase Rho-C-hCaS responsiveness. Compared with the Rho-C-hCaS control, the Rho-C-hCaS ${ }^{\mathrm{T} 888 \mathrm{~A}}$ mutant was more sensitive to $\mathrm{Ca}_{0}^{2+}\left(\mathrm{EC}_{50}, 1.8 \mathrm{Rho}-\mathrm{C}-\mathrm{hCaS}{ }^{\mathrm{T} 888 \mathrm{~A}}\right.$ vs. $2.8 \mathrm{mM}$ Rho-C-hCaS; $P<0.05$ ) (Fig. 5A), similar to the effect of T888A in the full-length CaS (Supplemental Fig. 4). In contrast, Rho-C-hCaS ${ }^{\mathrm{S} 875 \mathrm{~A}}$ did not exhibit significantly enhanced receptor responsiveness compared with Rho-C-hCaS $\left(\mathrm{EC}_{50}, 2.4\right.$ Rho-C-hCaS ${ }^{\mathrm{S} 875 \mathrm{~A}}$ vs. $2.8 \mathrm{mM}$ Rho-C-hCaS; $P=$ 0.18 . Therefore, when expressed alone in the headless receptor, only T888A exhibits greater $\mathrm{Ca}_{0}^{2+}$ sensitivity.

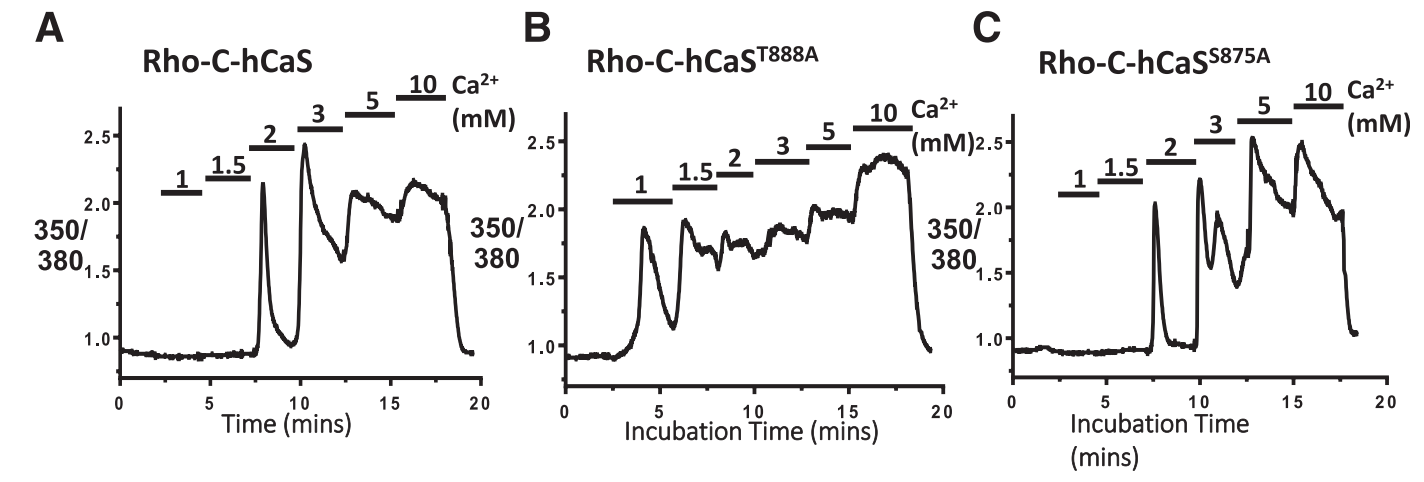

B

C

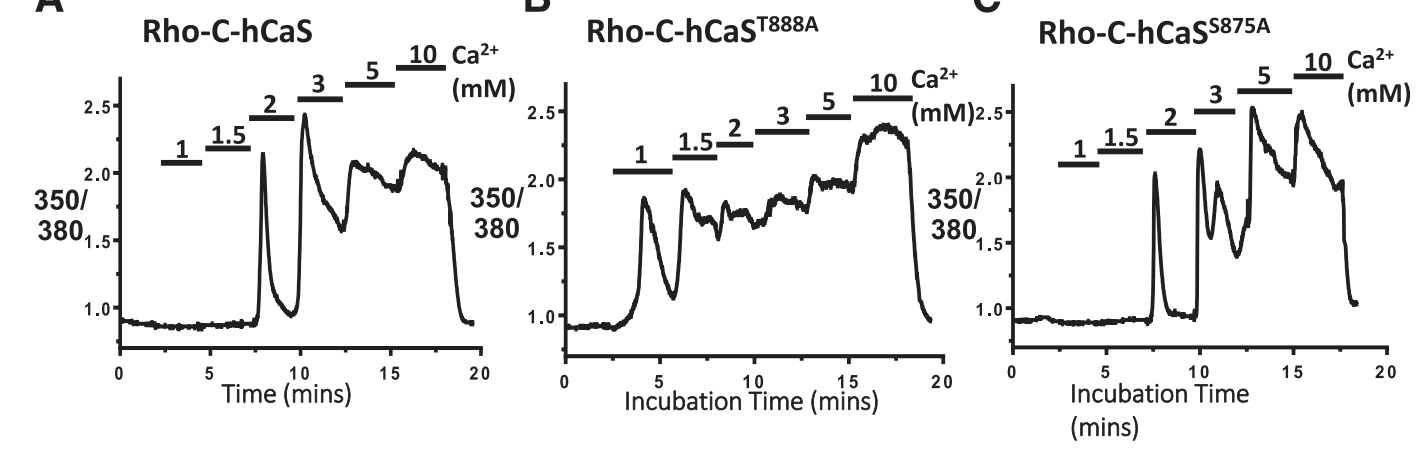

Rho-C-hCaS $5875 \mathrm{~A}$

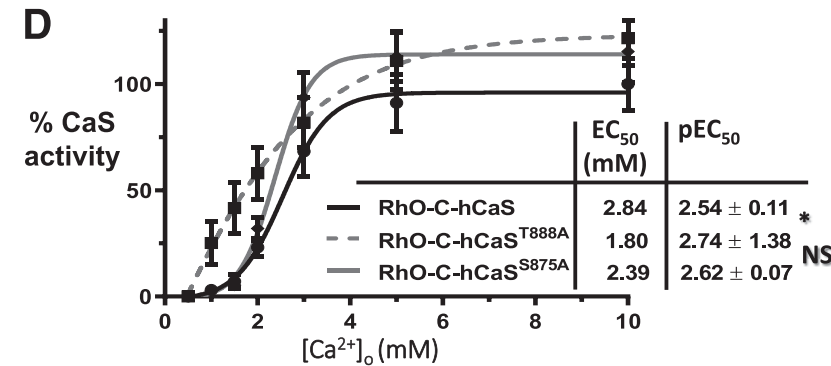

Fig. 5. T888A and S875A mutations enhance $\mathrm{Ca}_{\mathrm{i}}^{2+}$ mobilization of the ECD-deleted mutant, Rho-C-hCaS. Fura-2-loaded human embryonic kidney cells were transiently transfected with either Rho-C-hCaS (A), Rho-C-hCaS ${ }^{\mathrm{T} 888 \mathrm{~A}}(\mathrm{~B})$, or Rho-C-hCaS ${ }^{\mathrm{S} 875 \mathrm{~A}}(\mathrm{C})$ mutants, and then stimulated with increasing $\mathrm{Ca}_{\mathrm{o}}^{2+}$ concentrations $(0.5-10 \mathrm{mM})$. Representative $\mathrm{Ca}_{\mathrm{i}}^{2+}$ traces are shown. The resulting concentration-effect curves are shown in (D). $* P<0.05$, Rho-ChCaS vs. Rho-C-hCaS ${ }^{\mathrm{T} 88 \mathrm{~A}}$; NS, not significant, Rho-C-hCaS vs. Rho-C-hCaS ${ }^{\mathrm{S} 875 \mathrm{~A}}$ by one-way ANOVA with Dunnett's post hoc test; $n \geq 16$ coverslips from five independent experiments. 
Effect of Rho-C-hCaS ${ }^{\text {S875A/T888A }}$ Double Mutation on $\mathbf{C a}_{\mathbf{i}}^{2+}$ Mobilization. Finally, despite the S875A mutation having no significant effect on Rho-C-hCaS responsiveness on its own, we investigated whether this mutation may potentiate the enhanced responsiveness seen with Rho-C-hCaS ${ }^{\mathrm{T} 888 \mathrm{~A}}$ when expressed in combination. Indeed, the Rho-C-hCaS ${ }^{\mathrm{S} 875 \mathrm{~A} / \mathrm{T} 888 \mathrm{~A}}$ double mutant produced maximal $\mathrm{Ca}_{\mathrm{i}}^{2+}$ mobilization even under baseline conditions $\left(0.5 \mathrm{mM} \mathrm{Ca}^{2+}\right)$. However, this effect could be virtually abolished by cotreatment with the $\mathrm{CaS}$ negative allosteric modulator (calcilytic) $N$-(2-hydroxy-3-(2cyano-3-chlorophenoxy)propyl)-1,1-dimethyl-2-(2-nephthyl)ethylamine ( $1 \mu \mathrm{M} ; P<0.001)$ (Fig. 6B). To determine whether the Rho-C-hCaS ${ }^{\mathrm{S} 875 \mathrm{~A} / \mathrm{T} 888 \mathrm{~A}}$ double mutant is constitutively active, i.e., elicits continuous signaling even in the absence of an agonist, $\mathrm{Ca}_{\mathrm{i}}^{2+}$ mobilization was tested using a buffer that was nominally free of $\mathrm{Ca}^{2+}$ or $\mathrm{Mg}^{2+}$. As shown in Fig. 6, the Rho-C-hCaS ${ }^{\mathrm{S} 875 \mathrm{~A} / \mathrm{T} 888 \mathrm{~A}}$-induced $\mathrm{Ca}_{\mathrm{i}}^{2+}$ mobilization elicited in control buffer $\left(0.5 \mathrm{mM} \mathrm{Ca}^{2+}\right)$ was almost abolished upon removal of $\mathrm{Ca}_{\mathrm{o}}^{2+}$ and extracellular $\mathrm{Mg}^{2+}(P<0.001)$. Interestingly, introduction of $0.5 \mathrm{mM} \mathrm{Mg}^{2+}$ alone was sufficient to elicit cellular $\mathrm{Ca}_{\mathrm{i}}^{2+}$ transients in some coverslips. Subsequent introduction of $0.5 \mathrm{mM} \mathrm{Ca}{ }^{2+}$ restored maximal activation of the Rho-C-hCaS ${ }^{\mathrm{S} 875 \mathrm{~A} / \mathrm{T} 888 \mathrm{~A}}$ double mutant. Thus, although Rho-C-hCaS ${ }^{\text {S875A/T888A }}$ was not constitutively active, it exhibited substantially enhanced sensitivity to $\mathrm{Ca}_{\mathrm{o}}^{2+}$ (i.e., with a presumed $\mathrm{EC}_{50}<0.5 \mathrm{mM}$ ) despite the absence of an ECD. Together, these data demonstrate the importance of PKC-mediated Ser-875 and Thr-888 phosphorylation in the control of CaS signaling.

\section{Discussion}

Initial sequence analysis of the human CaS predicted that only five of the intracellular serine/threonine residues were likely to be PKC phosphorylation sites: two in the first and third intracellular loops (Thr-646 and Ser-794) and three in the ICD (Thr-888, Ser-895, and Ser-915) of the receptor (Garrett et al., 1995; Bai et al., 1998). Previous results have shown that one of these, $\mathrm{CaS}^{\mathrm{T} 888}$, represents the key phosphorylation site responsible for PKC-mediated inhibition of CaS-mediated $\mathrm{Ca}_{\mathrm{i}}^{2+}$ mobilization (Bai et al., 1998; Davies et al., 2007; Young et al., 2014). However, it should be noted that the human $\mathrm{CaS}$ has in fact 54 serine and threonine residues in either its ICD or three intracellular loops, although no tyrosine residues (Garrett et al., 1995). The NetPhos database predicts that 40 of these sites reach the threshold for being potential phosphorylation sites for at least one out of a panel of 17 protein kinases (http://www.cbs.dtu.dk/ services/NetPhos-3.1/). Interestingly, all of the serine/threonine residues in the juxtamembrane region of the ICD (residues 863-920) are predicted to be phosphorylation sites for one protein kinase or another, whereas in the later carboxyl-terminus few such residues are likely phosphorylation sites. In addition, this database predicts not five PKC sites in the CaS but 15 (including Ser-875), although it should also be noted that these predictions are based on primary sequence and do not take into account site accessibility or location. Nevertheless, current consensus site prediction databases indicate much greater scope for CaS phosphorylation than was considered when CaS was first cloned.

It has been suggested that where GPCRs have a variety of potential kinase consensus sequences, the precise pattern of phosphorylation on any given receptor could be quite different in different cellular contexts. The so-called phospho-barcode hypothesis posits that different patterns of phosphorylation could elicit distinct downstream signaling outcomes (Tobin et al., 2008; Yang et al., 2017). The barcode hypothesis was first devised by studying two GPCRs: the muscarinic acetylcholine receptor (Butcher et al., 2011) and the $\beta 2$-adrenergic receptor (Nobles et al., 2011). The present findings indicate
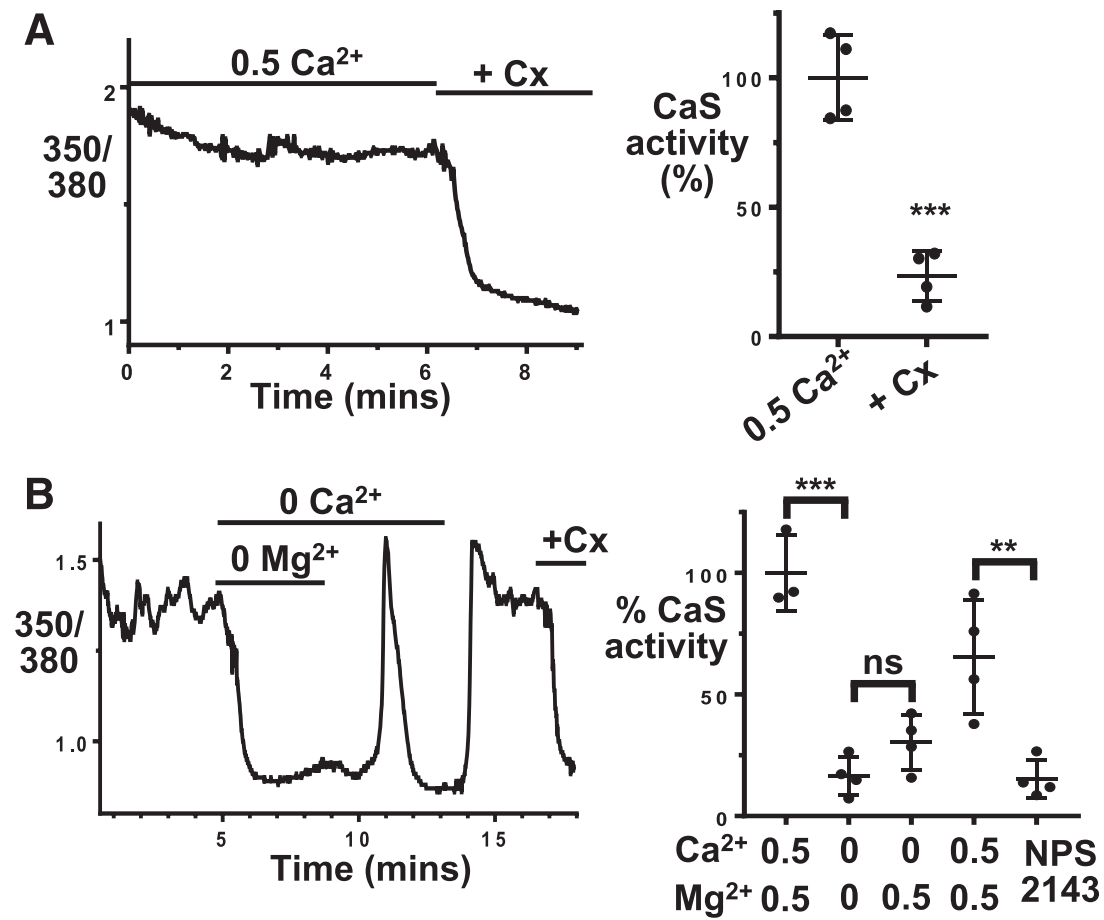

Fig. 6. Effect of $\mathrm{CaS}^{\mathrm{S} 875 \mathrm{~A} / \mathrm{T} 888 \mathrm{~A}}$ double mutation on Rho-C-hCaS. (A) Rho-C-hCaS ${ }^{\mathrm{S} 875 \mathrm{~A} / \mathrm{T} 888 \mathrm{~A}}$ transfected HEK-293 cells exhibited maximal $\mathrm{Ca}_{\mathrm{i}}^{2+}$ mobilization even under control conditions $\left(0.5 \mathrm{mM} \mathrm{Ca}_{0}^{2+}\right)$ but was substantially inhibited by calcilytic $(\mathrm{Cx}) \mathrm{N}$-(2-hydroxy-3(2-cyano-3-chlorophenoxy)propyl)-1,1-dimethyl-2-(2nephthyl)ethylamine (NPS-2143) $(1 \mu \mathrm{M}) . * * * P<0.001$ by paired $t$ test. (B) Rho-C-hCaS ${ }^{\mathrm{S} 875 \mathrm{~A} / \mathrm{T} 888 \mathrm{~A}}$-induced $\mathrm{Ca}_{\mathrm{i}}^{2+}$ mobilization was then assayed in the presence or absence of $0.5 \mathrm{mM} \mathrm{Ca}^{2+}$ and $0.5 \mathrm{mM} \mathrm{Mg^{2+ }}$ with resulting responses normalized to the $0.5 \mathrm{mM} \mathrm{Ca} \mathrm{Ca}_{\mathrm{o}}^{2+}$ response. $* * P<0.01 ; * * * P<0.001$ and NS, not significant by oneway ANOVA with Tukey's post hoc test; $n \geq 4$ coverslips from two independent experiments. 
that the CaS may also exhibit distinct phospho-barcodes in different cell types and/or following exposure to biased agonists or cotreatments with other GPCR agonists.

Consistent with the NetPhos database prediction and the current data, a phospho-proteomic study using mass spectrometry to detect phosphorylation sites in nine different organs from 3-week-old male mice has previously determined $\mathrm{CaS}^{\mathrm{S} 875}$ as a phosphorylation site in the kidney (Huttlin et al., 2010). This demonstrates that $\mathrm{CaS}^{\mathrm{S} 875}$ is capable of being phosphorylated in vivo. In addition, sequence alignment analysis of the ICDs of the CaS with the structurally homologous mGluR5 confirms that CaS Ser-875 is equivalent to the principal PKC phosphorylation site in mGluR5, namely, Ser-839 (MEGA-X software) (Supplemental Fig. 1A). Therefore, the alignment of $\mathrm{CaS}^{\mathrm{S} 875}$ and mGluR5 ${ }^{\mathrm{S} 839}$ suggests that they share similar regulatory roles in the modulation of receptor signaling. Moreover, the amino acid conservation of the putative Ser-875 phosphorylation site was examined in the current study across a previously published multiple sequences alignment of 51 different vertebrate $\mathrm{CaS}$ species (Herberger and Loretz, 2013) using the free WebLogo analysis website (https://weblogo.berkeley.edu/logo.cgi). As reflected by the high WebLogo bit scores (Supplemental Fig. 1B), $\mathrm{CaS}^{\mathrm{S} 875}$ is well conserved within different species. Overall, the conservation of Ser-875 is consistent with the phosphorylation site prediction and the strong functional role in $\mathrm{CaS}$ signaling. One important consideration regarding these phosphorylation sites is to determine whether they modulate signal transduction directly or instead by altering $\mathrm{CaS}$ cell surface localization (Breitwieser, 2013), as is apparently the case for $\mathrm{CaS}^{\mathrm{S} 899}$ (Grant et al., 2015). In this regard, we did not see a significant difference in the surface biotinylation of $\mathrm{CaS}^{\mathrm{S} 875 \mathrm{~A}}$ or $\mathrm{CaS}^{\mathrm{T} 888 \mathrm{~A}}$ versus $\mathrm{CaS}^{\mathrm{WT}}$ receptors. Nevertheless, it would be helpful to have a more thorough analysis of the effect of these and other CaS phospho-site point mutations on receptor maturation, forward trafficking, agonist-driven insertional signaling, internalization, and desensitization. However, in the meantime the current data establish a clear link between residues $\mathrm{CaS}^{\mathrm{S} 875}$ and $\mathrm{CaS}^{\mathrm{T} 888}$ and $\mathrm{CaS}$ downstream signaling.

In agreement with our previous study (Davies et al., 2007), $\mathrm{CaS}^{\mathrm{T} 888 \mathrm{~A}}$ elicits more sustained $\mathrm{Ca}_{i}^{2+}$ mobilization than $\mathrm{CaS}^{\mathrm{WT}}$. However, at lower $\mathrm{Ca}_{\mathrm{o}}^{2+}$ concentrations (1.5-2.5 mM) $\mathrm{Ca}_{\mathrm{i}}^{2+}$ oscillations continued in some $\mathrm{CaS}^{\text {T888A-expressing }}$ cells. Young et al. (2002) did not observe such oscillations in $\mathrm{CaS}^{\mathrm{T} 888 \mathrm{~A}}$-expressing cells, although only $3 \mathrm{mM} \mathrm{Ca}_{\mathrm{o}}^{2+}$ was used to stimulate the receptor in that study, and in our experiments $3 \mathrm{mM} \mathrm{Ca}{ }^{2+}$ also elicited only sustained $\mathrm{Ca}_{\mathrm{i}}^{2+}$ mobilization with $\mathrm{CaS}^{\mathrm{T} 888 \mathrm{~A}}$. Significantly, the persistence of $\mathrm{Ca}_{\mathrm{i}}^{2+}$ oscillations in $\mathrm{CaS}^{\mathrm{T} 888 \mathrm{~A}}$-transfected cells suggests that this site alone cannot be the exclusive phosphorylation location controlling $\mathrm{Ca}_{\mathrm{i}}^{2+}$ oscillations (Davies et al., 2007), meaning that an additional signaling determinant is required.

In support of this idea, Bai et al. (1998) previously showed that PKC activation by PMA reduced the responsiveness of a mutant $\mathrm{CaS}$, in which all five predicted PKC sites were eliminated. Moreover, PMA elicited a partial inhibitory effect in cells expressing $\mathrm{CaS}^{\mathrm{T} 888 \mathrm{~A}}$ (Davies et al., 2007) and $\mathrm{CaS}^{\mathrm{T} 888 \mathrm{M}}$ (Lazarus et al., 2011). Because PMA increases the phosphorylation of serine/threonine residues, these preserved inhibitory effects could be explained by the presence of an additional, previously unidentified PKC site(s) on the CaS.
As such, the current results indicate that Ser-875 is the previously unidentified PKC site. Specifically, $\mathrm{CaS}^{\mathrm{S} 875 \mathrm{~A}}$ with its nonphosphorylatable mutation enhanced signaling, whereas $\mathrm{CaS}^{\mathrm{S} 875 \mathrm{D}}$ with its phosphomimetic mutation inhibited signaling. Furthermore, the $\mathrm{CaS}^{\mathrm{S} 875 \mathrm{~A} / \mathrm{T} 888 \mathrm{~A}}$ double mutation further enhanced both $\mathrm{Ca}_{0}^{2+}$-induced $\mathrm{Ca}_{\mathrm{i}}^{2+}$ mobilization and ERK1/2 phosphorylation more than for $\mathrm{CaS}^{\mathrm{T} 888 \mathrm{~A}}$ alone, whereas concomitant PKC inhibition had no further effect. To prove that $\mathrm{CaS}^{\mathrm{S} 875}$ is a PKC site and then determine the ligand sensitivity of such phosphorylation, as was done for $\mathrm{CaS}^{\mathrm{T} 888}$ (Davies et al., 2007; McCormick et al., 2010), it will be necessary to raise a phospho-CaS ${ }^{\mathrm{S} 875}$-specific antibody. However, our initial attempt to generate such an antibody proved unsuccessful, and thus we must rely instead on the mutagenesis studies reported herein, the new consensus predictions described previously, the alignment to mGluR5 ${ }^{\mathrm{S} 839}$, and the previous murine proteomic data (Huttlin et al., 2010). On balance, we would argue that the simplest explanation of the current data is that $\mathrm{CaS}^{\mathrm{S} 875}$ is a functionally important PKC site, in conjunction with $\mathrm{CaS}^{\mathrm{T} 888}$. However, the possible involvement of other phosphorylation sites in the regulation of $\mathrm{CaS}$ function awaits determination.

That $\mathrm{CaS}^{\mathrm{S} 875 \mathrm{~A} / \mathrm{T} 888 \mathrm{~A}}$ expression failed to enhance carbachol signaling supported the idea that the gain of function was CaS specific and not an artifact of transfection. However, the observation that $\mathrm{CaS}^{\mathrm{S} 875 \mathrm{~A} / \mathrm{T} 888 \mathrm{~A}}$ expression, in fact, inhibited carbachol signaling is interesting. It is proposed that receptors exist in a conformational equilibrium between inactive and active states, and that $\mathrm{G}$ proteins have higher affinity for the active state of the receptor (Burstein et al., 1995). Since both CaS and the muscarinic acetylcholine receptor are $\mathrm{G} \alpha_{\mathrm{q}}$ coupled, it seems feasible that they compete for the same $\mathrm{G} \alpha_{\mathrm{q}}$-protein pool (Linderman, 2009), and thus perhaps $\mathrm{G} \alpha_{\mathrm{q}}$ has sufficiently higher affinity for the hyperactive $\mathrm{CaS}^{\mathrm{S} 875 \mathrm{~A} / \mathrm{T} 888 \mathrm{~A}}$ double mutant, such that fewer $\mathrm{G} \alpha_{\mathrm{q}}$ proteins were available to elicit the carbachol response. This issue requires further study.

Consistent with Mun et al. (2004), the Rho-C-hCaS mutant was sensitive to increasing concentrations of $\mathrm{Ca}_{\mathrm{o}}^{2+}$, which further verified the existence of at least one $\mathrm{Ca}_{\mathrm{o}}^{2+}$-binding site in the 7TMD of the CaS (Hammerland et al., 1999; Hu et al., 2002; Ray and Northup, 2002). This confirmation of the functional activity of the Rho-C-hCaS mutant allowed the determination of the role of PKC phosphorylation sites in a functionally active $\mathrm{CaS}$ that was not subject to control by the ECD. Introducing the mutation T888A to Rho-C-hCaS increased its $\mathrm{Ca}_{0}^{2+}$ sensitivity to that seen for the full-length $\mathrm{CaS}^{\mathrm{T} 888 \mathrm{~A}}$. Although Rho-C-hCaS ${ }^{\mathrm{S} 875 \mathrm{~A}}$ did not, on its own, enhance $\mathrm{Ca}_{0}^{2+}$ sensitivity (we observed a trend in this direction), the Rho-C-hCaS ${ }^{\mathrm{S} 875 \mathrm{~A} / \mathrm{T} 888 \mathrm{~A}}$ exhibited maximal $\mathrm{Ca}_{\mathrm{i}}^{2+}$ responsiveness even in control buffer. The response did not represent constitutive activity since Rho-C-hCaS ${ }^{\text {S875A/T888A }}$ could be suppressed by both calcilytic [N-(2-hydroxy-3-(2-cyano-3chlorophenoxy)propyl)-1,1-dimethyl-2-(2-nephthyl)ethylamine] cotreatment and exposure to nominally $\mathrm{Ca}^{2+} / \mathrm{Mg}^{2+}$-free buffer. These findings suggest that the TMD/proximal ICD core of the $\mathrm{CaS}$ might be much more $\mathrm{Ca}_{\mathrm{o}}^{2+}$ sensitive than is generally appreciated, and that the inactive form of the ECD and activation of the two PKC phosphorylation sites arrest its responsiveness. In summary, the present study has identified $\mathrm{CaS}^{\mathrm{S} 875}$ as a phosphorylation site that together with $\mathrm{CaS}^{\mathrm{T} 888}$ acts as a negative controller of CaS signaling and maintains 
$\mathrm{Ca}_{\mathrm{o}}^{2+}$-stimulated $\mathrm{Ca}_{\mathrm{i}}^{2+}$ oscillations that underpin CaS-mediated control of $\mathrm{Ca}_{\mathrm{o}}^{2+}$ homeostasis.

\section{Acknowledgments}

The authors thank Dr. R. Mun (The Charles Perkins Centre, The University of Sydney, Camperdown, Australia) for providing the Rho-C-hCaS mutant construct and also Kathryn Bailey and Dr. Sarah Davies for technical assistance.

\section{Authorship Contributions}

Participated in research design: Binmahfouz, Conigrave, Ward.

Conducted experiments: Binmahfouz, Centeno.

Contributed new reagents or analytic tools: Conigrave.

Performed data analysis: Binmahfouz.

Wrote or contributed to the writing of the manuscript: Binmahfouz, Conigrave, Ward.

\section{References}

Atwood BK, Lopez J, Wager-Miller J, Mackie K, and Straiker A (2011) Expression of G protein-coupled receptors and related proteins in HEK293, AtT20, BV2, and N18 cell lines as revealed by microarray analysis. BMC Genomics 12:14.

Bai M, Quinn S, Trivedi S, Kifor O, Pearce SHS, Pollak MR, Krapcho K, Hebert SC, and Brown EM (1996) Expression and characterization of inactivating and activating mutations in the human $\mathrm{Ca}^{2+}{ }_{{ }}$-sensing receptor. $J$ Biol Chem 271: 19537-19545.

Bai M, Trivedi S, Lane CR, Yang Y, Quinn SJ, and Brown EM (1998) Protein kinase $\mathrm{C}$ phosphorylation of threonine at position 888 in $\mathrm{Ca}^{2+}{ }_{0}$-sensing receptor $(\mathrm{CaR})$ inhibits coupling to $\mathrm{Ca}^{2+}$ store release. J Biol Chem 273:21267-21275.

Bräuner-Osborne H, Jensen AA, Sheppard PO, O'Hara P, and Krogsgaard-Larsen P (1999) The agonist-binding domain of the calcium-sensing receptor is located the amino-terminal domain. J Biol Chem 274:18382-18386.

Breitwieser GE (2013) The calcium sensing receptor life cycle: trafficking, cell surface expression, and degradation. Best Pract Res Clin Endocrinol Metab 27:303-313.

Burstein ES, Spalding TA, Braüner-Osborne H, and Brann MR (1995) Constitutive activation of muscarinic receptors by the G-protein $\mathrm{G}_{\mathrm{q}}$. FEBS Lett 363:261-263.

Butcher AJ, Prihandoko R, Kong KC, McWilliams P, Edwards JM, Bottrill A, Mistry S, and Tobin $\mathrm{AB}$ (2011) Differential G-protein-coupled receptor phosphorylation provides evidence for a signaling bar code. J Biol Chem 286:11506-11518.

Dale LB, Babwah AV, Bhattacharya M, Kelvin DJ, and Ferguson SSG (2001) Spatialtemporal patterning of metabotropic glutamate receptor-mediated inositol 1,4,5 triphosphate, calcium, and protein kinase $\mathrm{C}$ oscillations: protein kinase $\mathrm{C}$-dependent receptor phosphorylation is not required. J Biol Chem 276:35900-35908.

Davies SL, Ozawa A, McCormick WD, Dvorak MM, and Ward DT (2007) Protein kinase C-mediated phosphorylation of the calcium-sensing receptor is stimulated by receptor activation and attenuated by calyculin-sensitive phosphatase activity. $J$ Biol Chem 282:15048-15056.

Garrett JE, Capuano IV, Hammerland LG, Hung BCP, Brown EM, Hebert SC, Nemeth EF, and Fuller F (1995) Molecular cloning and functional expression of human parathyroid calcium receptor cDNAs. J Biol Chem 270:12919-12925.

Geng Y, Mosyak L, Kurinov I, Zuo H, Sturchler E, Cheng TC, Subramanyam P, Brown AP, Brennan SC, Mun HC, et al. (2016) Structural mechanism of ligand activation in human calcium-sensing receptor. eLife $\mathbf{5}$ :e13662.

Grant MP, Cavanaugh A, and Breitwieser GE (2015) 14-3-3 proteins buffer intracellular calcium sensing receptors to constrain signaling. PLoS One 10:e136702.

Grant MP, Stepanchick A, Cavanaugh A, and Breitwieser GE (2011) Agonist-driven maturation and plasma membrane insertion of calcium-sensing receptors dynamically control signal amplitude. Sci Signal 4:ra78.

Hammerland LG, Krapcho KJ, Garrett JE, Alasti N, Hung BCP, Simin RT, Levinthal C, Nemeth EF, and Fuller FH (1999) Domains determining ligand specificity for $\mathrm{Ca}^{2+}$ receptors. Mol Pharmacol 55:642-648.
Herberger AL and Loretz CA (2013) Vertebrate extracellular calcium-sensing receptor evolution: selection in relation to life history and habitat. Comp Biochem Physiol Part D Genomics Proteomics 8:86-94.

Hermans E and Challiss RA (2001) Structural, signalling and regulatory properties of the group I metabotropic glutamate receptors: prototypic family C G-protein-coupled receptors. Biochem J 359:465-484.

Hu J, Reyes-Cruz G, Chen W, Jacobson KA, and Spiegel AM (2002) Identification of acidic residues in the extracellular loops of the seven-transmembrane domain of the human $\mathrm{Ca}^{2+}$ receptor critical for response to $\mathrm{Ca}^{2+}$ and a positive allosteric modulator. J Biol Chem 277:46622-46631.

Huttlin EL, Jedrychowski MP, Elias JE, Goswami T, Rad R, Beausoleil SA, Villén J, Haas W, Sowa ME, and Gygi SP (2010) A tissue-specific atlas of mouse protein phosphorylation and expression. Cell 143:1174-1189.

Kim CH, Braud S, Isaac JTR, and Roche KW (2005) Protein kinase C phosphorylation of the metabotropic glutamate receptor mGluR5 on Serine 839 regulates $\mathrm{Ca}^{2+}$ oscillations. $J$ Biol Chem 280:25409-25415.

Lazarus S, Pretorius CJ, Khafagi F, Campion KL, Brennan SC, Conigrave AD, Brown EM, and Ward DT (2011) A novel mutation of the primary protein kinase C phosphorylation site in the calcium-sensing receptor causes autosomal dominant hypocalcemia. Eur J Endocrinol 164:429-435.

Linderman JJ (2009) Modeling of G-protein-coupled receptor signaling pathways. $J$ Biol Chem 284:5427-5431.

McCormick WD, Atkinson-Dell R, Campion KL, Mun H-C, Conigrave AD, and Ward DT (2010) Increased receptor stimulation elicits differential calcium-sensing receptor T888 dephosphorylation. J Biol Chem 285:14170-14177.

Mun HC, Franks AH, Culverston EL, Krapcho K, Nemeth EF, and Conigrave AD (2004) The Venus Fly Trap domain of the extracellular $\mathrm{Ca}^{2+}$-sensing receptor is required for L-amino acid sensing. J Biol Chem 279:51739-51744.

Nobles KN, Xiao K, Ahn S, Shukla AK, Lam CM, Rajagopal S, Strachan RT, Huang TY, Bressler EA, Hara MR, et al. (2011) Distinct phosphorylation sites on the $\beta_{2}$-adrenergic receptor establish a barcode that encodes differential functions of $\beta$-arrestin. Sci Signal 4:ra51.

Ray K and Northup J (2002) Evidence for distinct cation and calcimimetic compound (NPS 568) recognition domains in the transmembrane regions of the human $\mathrm{Ca}^{2+}$ receptor. J Biol Chem 277:18908-18913.

Tobin AB, Butcher AJ, and Kong KC (2008) Location, location, location...site-specific GPCR phosphorylation offers a mechanism for cell-type-specific signalling. Trends Pharmacol Sci 29:413-420.

Ward DT, Brown EM, and Harris HW (1998) Disulfide bonds in the extracellular calcium-polyvalent cation-sensing receptor correlate with dimer formation and its response to divalent cations in vitro. J Biol Chem 273:14476-14483.

Ward DT, McLarnon SJ, and Riccardi D (2002) Aminoglycosides increase intracellular calcium levels and ERK activity in proximal tubular OK cells expressing the extracellular calcium-sensing receptor. J Am Soc Nephrol 13:1481-1489.

Yang Z, Yang F, Zhang D, Liu Z, Lin A, Liu C, Xiao P, Yu X, and Sun JP (2017) Phosphorylation of $\mathrm{G}$ protein-coupled receptors: from the barcode hypothesis to the flute model. Mol Pharmacol 92:201-210.

Young SH, Rey O, Sinnett-Smith J, and Rozengurt E (2014) Intracellular $\mathrm{Ca}^{2+}$ oscillations generated via the $\mathrm{Ca}^{2+}$-sensing receptor are mediated by negative feedback by PKC $\alpha$ at Thr ${ }^{888}$. Am J Physiol Cell Physiol 306:C298-C306.

Young SH, Wu SV, and Rozengurt E (2002) $\mathrm{Ca}^{2+}$-stimulated $\mathrm{Ca}^{2+}$ oscillations produced by the $\mathrm{Ca}^{2+}$-sensing receptor require negative feedback by protein kinase $\mathrm{C}$. $J$ Biol Chem 277:46871-46876.

Zhang C, Zhang T, Zou J, Miller CL, Gorkhali R, Yang JY, Schilmiller A, Wang S, Huang K, Brown EM, et al. (2016) Structural basis for regulation of human calcium-sensing receptor by magnesium ions and an unexpected tryptophan derivative co-agonist. Sci Adv 2:e1600241.

Zhao XM, Hauache O, Goldsmith PK, Collins R, and Spiegel AM (1999) A missense mutation in the seventh transmembrane domain constitutively activates the human $\mathrm{Ca}^{2+}$ receptor. FEBS Lett 448:180-184.

Address correspondence to: Dr. Donald T. Ward, Faculty of Biology, Medicine and Health, Michael Smith Building, The University of Manchester, Manchester M13 9PT, UK. E-mail: d.ward@manchester.ac.uk 